\title{
A Multicenter Proposal for a Fast Tool To Screen Biosecure Chicken Flocks for the Foodborne Pathogen Campylobacter
}

Hoorfar, Jeffrey; Koláková, Ivana; Johannessen, Gro S; Garofolo, Giuliano; Marotta, Francesca; Wieczorek, Kinga; Osek, Jacek; Torp, Mona; Spilsberg, Bjørn; Sekse, Camilla

Total number of authors:

12

Published in:

Applied and Environmental Microbiology

Link to article, DOI:

10.1128/AEM.01051-20

Publication date:

2020

Document Version

Peer reviewed version

Link back to DTU Orbit

Citation (APA):

Hoorfar, J., Koláková, I., Johannessen, G. S., Garofolo, G., Marotta, F., Wieczorek, K., Osek, J., Torp, M. Spilsberg, B., Sekse, C., Thornval, N. R., \& Karpíšková, R. (2020). A Multicenter Proposal for a Fast Tool To Screen Biosecure Chicken Flocks for the Foodborne Pathogen Campylobacter. Applied and Environmental Microbiology, 86(20), [e01051-20]. https://doi.org/10.1128/AEM.01051-20

\section{General rights}

Copyright and moral rights for the publications made accessible in the public portal are retained by the authors and/or other copyright owners and it is a condition of accessing publications that users recognise and abide by the legal requirements associated with these rights.

- Users may download and print one copy of any publication from the public portal for the purpose of private study or research.

- You may not further distribute the material or use it for any profit-making activity or commercial gain

- You may freely distribute the URL identifying the publication in the public portal 
4 Authors: Jeffrey Hoorfar ${ }^{1}$, Ivana Koláčková ${ }^{2}$, Gro S. Johannessen ${ }^{3}$, Giuliano Garofolo ${ }^{4}$,

5 Francesca Marotta ${ }^{4}$, Kinga Wieczorek ${ }^{5}$, Jacek Osek ${ }^{5}$, Mona Torp ${ }^{3}$, Bjørn Spilsberg ${ }^{3}$, Camilla

6 Sekse ${ }^{3}$, Natasia Rebekka Thornval ${ }^{1}$, Renáta Karpíšková ${ }^{2}$

7

8

Foodborne Campylobacter: A multi-center proposal for a fast screening tool in biosecured chicken flocks

\section{Date of submission: May 6}

${ }^{1}$ National Food Institute, Technical University of Denmark, Kemitorvet, DK-2800 Kongens

Lyngby, Denmark.

${ }^{2}$ Veterinary Research Institute, Hudcova 296/70, 62100 Brno, Czech Republic

${ }^{3}$ Norwegian Veterinary Institute, P.O. Box 750 Sentrum, 0106 Oslo, Norway

${ }^{4}$ National Reference Laboratory for Campylobacter, Istituto Zooprofilattico Sperimentale dell’Abruzzo e del Molise, 64100 Teramo, Italy

${ }^{5}$ National Veterinary Research Institute, Partyzantow 57, 24-100 Pulawy, Poland

Corresponding author: Jeffrey Hoorfar, jhoo@food.dtu.dk, National Food Institute, Technical University of Denmark, Kemitorvet, DK-2800 Kongens Lyngby, Denmark,

\section{Keywords:}

zoonoses; air sampling; PCR, campylobacteriosis; risk assessment. 


\section{Abstract}

The present multi-centre study aimed at assessing the performance of air sampling as a novel method for monitoring Campylobacter in biosecured poultry farms. We compared, using a harmonized procedure, the bacteriological isolation protocol (ISO 10272-1:2017), and a realtime PCR method on air filter samples. Air samples and boot swabs were collected from 62 biosecured flocks from five European countries during the summer of 2019. For air filters, the frequency of PCR-positive findings was significantly higher $(n=36 ; 58 \%)$ compared to the cultivation methods ( $p<0.01$; Standardized Residuals). The cultivation protocols (one with Bolton enrichment and one with Preston enrichment) were comparable to each other, but returned fewer positive samples (0-8\%). The association between type of sample and frequency of PCR-positive findings was statistically confirmed ( $p<0.01$; Fisher's exact test), although no culture-positive air filters were detected using direct plating. For the boot swabs, the highest number of positive samples were detected after enrichment in Preston broth $(n=23 ; 37 \%)$, followed by direct plating after homogenization in Preston $(n=21 ; 34 \%)$ or Bolton ( $\mathrm{n}=20 ; 32 \%)$. It is noteworthy that the Norwegian flocks, a country known to have low Campylobacter prevalence in biosecured chicken flocks, tested negative for Campylobacter using the new sensitive approach. In conclusion, air sampling combined with real-time PCR is proposed as a multi-purpose, low-cost and convenient screening method that can be up to four times faster and four times more sensitive than the current boot-swab testing scheme used for screening biosecured chicken production.

\section{Importance}

Campylobacter bacteria are the cause of the vast majority of registered cases of foodborne illness in the industrialized world. In fact, the bacteria caused 246,571 registered cases of foodborne illness in 2018, which equates to $70 \%$ of all registered cases in Europe that year. 
An important tool to prevent campylobacter from making people sick is good data on where in the food chain the bacterium is present. The present study reports a new test method that quadruples the likelihood of identifying campylobacter-positive chicken flocks. It is important to identify campylobacter-positive flocks before they arrive at the slaughterhouse. This is because negative flocks may be slaughtered first in the morning in order to avoid crosscontamination along the production line.

\section{Introduction}

Campylobacter spp. infection is one of the most widespread foodborne infectious diseases of the last century $(1,2)$. The incidence and prevalence of Campylobacteriosis have increased in both developed and developing countries over the last 10 years and is the leading cause of foodborne illness in the United States (3) and the EU (4). The dramatic increase in the industrialized world is alarming, and data from parts of Africa, Asia, and the Middle East indicate that Campylobacteriosis is endemic in these areas, especially in children (2). coat the exterior of the bird and remain attached to the skin (6). production systems (1, 8). An amendment to EC Regulation No 2073/2005 brings Campylobacter sampling processes, limits and corrective actions, in line with 

for poultry producers is a requirement to comply with a limit of $1000 \mathrm{CFU} / \mathrm{g}$ in at least 60 percent of chickens tested. It is important to note that they set an indicative the hygiene of the process in compliance with the legislation.

Proper sampling can facilitate the monitoring of Campylobacter on farm and before dispatch for slaughtering. However, current sampling techniques are mostly a century-old and need modernization in order to adapt to automated and molecular detection techniques, reduce the cost of handling and transport, and provide faster laboratory results close to, or in real-time for multi-pathogen testing (10). At present, on-farm sampling of poultry is done by taking faecal droppings or boot swabs (11). Additionally, upon collecting or hanging chickens for slaughter, cloacae swabbing or caecum sampling is performed.

The occurrence of Campylobacter in the primary production can be studied by sampling poultry and the surrounding environment $(12,13,14,15)$. A composite sample approach is often applied, pooling multiple swabs (5-10). Ventilation shafts, dust on surfaces, floors, transport crates, etc. can be sampled with moist gauze swabs (16). Drinking water can be taken directly from the tap in the poultry house or outdoor water supplies and collected in sterile containers.

A novel method to screen for Campylobacter is sampling of air on gelatine filters $(11,17)$, which has been previously demonstrated to detect the presence of Campylobacter in ambient air from chicken flocks in production houses, in some cases even earlier than the current conventional and costly methods $(14,17,18)$. We report here a harmonized multi-center study to assess the diagnostic sensitivity of air sampling protocol in biosecured farms in five different climatic and geographical regions of Europe with different epidemiology; Norway has a low reported prevalence of Campylobacter in chickens, while Italy has a high prevalence of Campylobacter-contaminated chicken flocks. 


\section{Materials and methods}

98

\section{1 Study design}

The sampling was carried out in the Czech Republic, Denmark, Italy, Norway, and Poland to include European regions with different geographical origin, climate, as well as different level of Campylobacter prevalence in chicken flocks. Each laboratory collected samples from at least 10 chicken flocks from at least two separate biosecured chicken farms as described by Johannessen et al. (18), with some modifications as presented below. Three samples were taken from each flock, a pair of boot swabs and two air filters giving a total number of 186 samples.

\subsection{Sample collection}

The samples were collected as described by Johannessen et al. (18). Briefly, before the sampling, boot swabs were moistened in a sterile diluent or pre-moistened boot swabs were used. The person performing the sampling wore the swabs over boots and walked around the chicken house covering as much area as possible (19).

The air samples were taken using the AirPort MD8 device (Sartorius Stedim Biotech, France) with disposable gelatine membrane filters (80 $\mathrm{mm}$ in diameter; Sartorius 17528-80ACD) as described by Johannessen et al (2020). Briefly, the samples were taken using an airflow rate of $50 \mathrm{~L} / \mathrm{min}$ for $15 \mathrm{~min}$ giving a total air volume of $750 \mathrm{~L}$. The samples were transported at $4^{\circ} \mathrm{C}$ conditions to the laboratory and processed within $48 \mathrm{hrs}$ for cultivation, or within five days for DNA extraction and the following real-time PCR. The details about sampling periods and flocks in each country are shown in Supplementary data, S1. 
2.3. Analyses

\subsubsection{Cultivation method}

ISO 10272-1:2017 was used for detection of Campylobacter (20). Direct plating from homogenates prior to enrichment were included as described below. The steps of cultivation of boot swabs and air filters are presented in Fig. 1a and Fig 1b.

\subsubsection{Boot socks/swabs}

A total of 62 boot swab samples were collected. Briefly, the boot swab sample were split in two parts (Figure 1a). Each boot swab was weighted separately and Bolton broth or Preston broth was added to obtain a ratio 1:10 (w/v). Prior to incubation of the Bolton and Preston broths, a $10 \mu \mathrm{l}$ aliquot of Bolton broth was plated directly on modified Charcoal Cefoperazone Deoxycholate (mCCDA) plate and a second agar plate of own choice, while 10 $\mu 1$ of Preston broth was plated on mCCDA, only. The plates were incubated in micro-aerobic conditions at $41.5{ }^{\circ} \mathrm{C}$ for $44 \pm 4 \mathrm{hrs}$. The Bolton and Preston broths were incubated at $41.5{ }^{\circ} \mathrm{C}$ for $44 \pm 4 \mathrm{hrs}$ and $41.5{ }^{\circ} \mathrm{C}$ for $24 \pm 2 \mathrm{hrs}$, respectively, followed by subsequent plating as described for direct plating above. After incubation, the plates were checked for the presence of typical Campylobacter colonies, and a total of three presumptive Campylobacter colonies from each enrichment procedure were confirmed using the routine confirmation test used in the respective laboratories. Additionally, aliquots of the enrichment broths from every step were frozen at $\leq 70^{\circ} \mathrm{C}$ after adding glycerol to a final concentration of $15 \%$.

\subsubsection{Air filters}


A total of 124 air filters were collected (two filters per chicken house). One of two air filters was used for cultivation as shown in Fig. 1b. The filter was split in two halves, to which $10 \mathrm{ml}$ of Bolton broth was added to one of the halves, and $10 \mathrm{ml}$ of Preston broth was added to the other half. The plating and incubation steps were carried out as described for boot sock samples.

\subsubsection{Real-time PCR}

The second air filter was used for DNA extraction and real-time PCR for the detection of Campylobacter. The air filter was split in two halves and DNA was extracted separately from each half using the same protocol. Briefly, the filter was pre-treated by dissolving a half in 3.5 $\mathrm{ml}$ molecular grade water tempered to room temperature with $100 \mu \mathrm{l}$ of alkaline protease (Protex GL, Genencor International, Leiden, The Netherlands). The suspension was vortexed and split into two tubes with equal volumes. Then, the tubes were incubated in a thermal shaker for $6 \mathrm{~min}$ at $37^{\circ} \mathrm{C}$ at $1000 \mathrm{RPM}$ and subsequently centrifuged at $8000 \mathrm{x} g$ for $5 \mathrm{~min}$ at $4^{\circ} \mathrm{C}$. The supernatant was discarded and the pellet was used for DNA extraction with DNeasy Blood \& Tissue Kit (Qiagen GmbH, Germany) according to manufacturer's instructions with modifications as described below. After incubation at $56^{\circ} \mathrm{C}$ for one hour with shaking the samples were cooled down to $40^{\circ} \mathrm{C}$ and $4 \mu \mathrm{l}$ of RNase A (100 mg/ml; Qiagen) was added, vortexed and incubated at room temperature for $5 \mathrm{~min}$. DNA was eluted from the spin column with $100 \mu \mathrm{TE}$ buffer with $0.1 \mathrm{mM}$ EDTA pre-warmed to $70^{\circ} \mathrm{C}$ and incubated at room temperature for $1 \mathrm{~min}$ before centrifugation. DNA was stored at $-20^{\circ} \mathrm{C}$ for short time storage, and at $-80^{\circ} \mathrm{C}$ for longer storage.

Real-time PCR was done as described by Josefsen et al. (21) using master mix and reagents prepared centrally by the Danish partner and distributed to all participants in advance. PCR 
were performed in $10 \mathrm{mM}$ Tris- $\mathrm{HCl} \mathrm{pH} 8.9,0.1 \mathrm{M} \mathrm{KCl}, 4 \mathrm{mM} \mathrm{MgCl} 2,7 \%$ glycerol, $0.6 \mathrm{mM}$ $\mathrm{dNTP}, 250 \mu \mathrm{g} / \mathrm{ml}$ bovine serum albumin and $1 \mathrm{U}$ of Tth DNA polymerase, with $500 \mathrm{nM}$ of forward primer (5'-CTGCTTAACACAAGTTGAGTAGG-3'), $500 \mathrm{nM}$ of reverse primer (5'TTCCTTAGGTACCGTCAGAA-3') and $75 \mathrm{nM}$ of LNA probe (5'-FAM-

$\mathrm{CA}[+\mathrm{T}] \mathrm{CC}[+\mathrm{T}] \mathrm{CCACGCGGCG}[+\mathrm{T}] \mathrm{TGC}-\mathrm{BHQ} 1-3 ')$. This assay will detect Campylobacter jejuni, C. coli and C. lari. An Internal Amplification Control (IAC) was included in the same PCR reaction, using the same primers and $50 \mathrm{nM}$ of5'-Joe-

+TTCATGAGGACACCTGAGTTGA-tamra3' probe in a duplex reaction. Template for the IAC were $5 \times 10^{3}$ copies of IAC (124 bp) with the sequence,

\section{CTGCTIAACACAAGTTGAGTAGGCAACTCAGGTGTCCTCATGAATTIGAAGA}

\section{CATAAACAAGGGACTGGTCTCCGTCCCAACCAAGATCATCCATCTCCCGCTATTC}

TGACGGTACCTAAG GAA. The cycle profile was as follows: initial denaturation at $95^{\circ} \mathrm{C}$

for $3 \mathrm{~min}$, followed by 40 cycles of $95^{\circ} \mathrm{C}$ for $15 \mathrm{~s}$ and $58^{\circ} \mathrm{C}$ for $60 \mathrm{~s}$. A cutoff value of $\mathrm{Ct}<36$ was used to score positive samples as recommended by Josefsen et al. (21).

\subsubsection{Statistical analysis}

Statistical analysis was performed using Fisher's exact test, McNemar test and Chi-square test (Statistica 13.2, Dell, USA). A p-value of less than 0.05 was considered as statistically significant. Relative sensitivity, specificity and diagnostic accuracy were calculated according to Malorny et al. (22). The formulas used for the analysis were:

Relative sensitivity $(\%)=100 \times($ positive agreement between culture and PCR $) /($ positive agreement between culture and PCR)+(false-negatives by PCR);

Relative specificity $(\%)=100 \times($ negative agreement between culture and PCR $) /($ negative agreement between culture and PCR)+(false-positives by PCR); 
Diagnostic accuracy $(\%)=100 \times$ (positive and negative agreement between culture and PCR)/total number of samples tested.

\section{Results}

A total of 62 chicken houses/flocks in five countries were visited and sampled from March to August 2019. Italy and Norway sampled 10 houses/flocks each, the Czech Republic and Poland 12 houses/flocks, while Denmark sampled 18 houses/flocks.

All samples examined in Norway were negative. On the contrary, in Italy all boot swabs were Campylobacter positive (Table 1), the same as the corresponding air filters examined using real-time PCR (Table 2).

\subsection{Cultivation method}

\subsubsection{Boot swabs}

Using the direct plating approach, $33.8 \%$ (21) and 32.2\% (20) of boot swabs homogenized in Preston and Bolton broth, respectively, were Campylobacter positive (Table 1). Enrichment in Preston, however, yielded $37.1 \%$ (23) positive boot swabs compared to enrichment in Bolton, where only $16.1 \%$ (10) of positive samples was detected (Table 1).

The comparison between the two types of cultivation approaches (direct plating and enrichment) showed that direct plating and enrichment in Preston were not statistically different while the Bolton enrichment showed a frequency of positive finding (16.1\%) significantly lower compared to direct plating ( $\mathrm{p}<0.05$; McNemar test) but also versus enrichment in Preston broth $(\mathrm{p}<0.001$; Chi-square test). 


\subsubsection{Air filters}

By cultivation, Campylobacter was detected only in four (6.5\%) and six (9.7\%) air filters after enrichment in Preston and Bolton broth, respectively (Table 2). Direct plating did not yield positive results from any of the air filters. Real-time PCR gave positive results for DNA specific for Campylobacter in 58\% $(n=36)$ of all the tested air filters $(n=62)$. (Table 2 and the supplementary data, S1). The frequency of positive findings in air filters using PCR was statistically significantly higher compared to cultivation methods $(\mathrm{p}<0.01$; standardized residuals). Comparison between microbiological and molecular methods used showed that molecular methods had a statistically significant higher frequency of detection of Campylobacter ( $\mathrm{p}<0.05$; Fisher's exact test).

\subsection{Campylobacter spp. findings by flocks}

Out of 62 tested flocks, 25 were negative by all methods. In 27 flocks out of 36 positive by PCR analysis of air filters, presence of Campylobacter was confirmed in corresponding boot swabs using cultivation method (direct plating or enrichment approach). Only one flock was positive exclusively from boot swab samples, using enrichment in Preston (Poland - 2/4; see supplementary data $\mathrm{S} 1$ ). The sensitivity of the detection approach, which employs air filter combined with real-time PCR detection, compared to boot swabs examined by cultivation method, was determined to be $96.4 \%$, its specificity $73.5 \%$ and diagnostic accuracy $83.8 \%$ (Table 3).

\section{Discussion}

Campylobacter spp. is one of the most important pathogens in relation to the chicken meat production and it is the aetiological agent of the most frequent zoonosis in the industrialized world for more than a decade. Chicken flocks represent the main reservoir, and current 
strategies to control Campylobacters on farm level, mainly based on the farm biosecurity, seem to be insufficient. Healthy but caecal carrier chickens are shedding Campylobacters in the farm environment and they are considered to be the most important source of contamination of carcases during their processing at the slaughterhouse level (23). Proper management on farms including welfare practices together with efficient sampling method can improve the food safety of poultry meat chain at slaughterhouse and retail level.

The usual critique of more sensitive methods is that they are too sensitive and detect contaminated flocks where they should not, which is why it was important to compare the new sampling approach with the conventional swab methods in geographical regions with different prevalence of Campylobacter. The air sampling protocol in combination with realtime PCR, found no contaminated flocks in Norway, while this figure was 100\% in Italy. Such differences might be due to climate conditions, environmental pressure and various infection rates in chickens identified in the countries participating in the present study $(5,24$, 25).

Comparison of the result from real-time PCR directly on the filters with the method utilizing cultivation of air filters in two different broths revealed that the PCR-based approach had an advantage over the culture method, which identified only $9.7 \%$ of positive samples (enrichment in Bolton broth). However, detection of Campylobacter in filters using direct plating identified no positive samples. The direct PCR results obtained, were then related to a commonly used method of faeces collection by boot swabs, utilized for e.g. Salmonella monitoring in poultry flocks (26). The filter and boot swab samples were collected in parallel in the five participating countries using the standardized protocols. Among 62 samples of boot swabs, $37.1 \%$ flocks were positive in this method (enrichment in Preston broth). The cultivation from boot swabs indicated that direct plating and Preston enrichment worked better than compared to direct plating and enrichment in Bolton, highlighting that these 
particular samples a high background flora together with the Campylobacters present.

Comparing the cultivation results from boot swabs and air filters indicated that more positive Campylobacter boot swabs were identified as compared to cultivation of air filters. However, Campylobacter was identified in more of the tested chicken flocks when air filters and direct real-time PCR were applied as compared to cultivation of boot swabs. Taking into account all above mentioned findings it can be suggested that the most efficient approach to detect Campylobacter in chicken flocks was the use of filters together with real-time PCR. The low number of positive flocks obtained from the cultivation of air samples in the study was probably the result of adverse environmental conditions present on filters. These observations are in agreement with our earlier results on the comparison of filter and culture methods for detection of Campylobacter in chickens (18).

The high detection rate in the direct air filter real-time PCR approach obtained in the present study was probably due to identification of all Campylobacter, including live, dead, and viable but not culturable cells (VBNC) as well as extracellular DNA of these bacteria. However, since the molecular method is intended for use as a screening tool, differentiation between dead and live cells is not so crucial.

With regard to the sampling place, poultry houses with all-in/ all-out management and regular disinfection, it can be assumed that the PCR positive findings reflect the reality of flock's positivity more closely than cultivation method. Furthermore, previous studies have also indicated that the air filter sampling method combined with real-time PCR allowed for a much earlier detection of flock contamination (up to two weeks) compared to the currently used boot swabs $(11,17)$. However, this should be further investigated with studies in geographical regions with different prevalence of Campylobacter in chicken flocks following farms over time. As real-time PCR is a more sensitive method than traditional cultivation of Campylobacter, the boot swabs could also be analysed using the same real-time PCR as for 
the air filters for a more direct comparison of methods in future studies. Such early results may be important for a subsequent investigation of the flock contamination level and epidemiological analyses. In a follow-up, shotgun metagenomics will also be applied on the same air filter samples investigated in this study for investigating the microbiome and the resistome of the air samples from the chicken houses as well as for comparison of detection of Campylobacter by a different technology.

The results obtained, based on the harmonized air sampling protocol established during the present study and tested in different parts of Europe indicate that the method can be useful in various countries and chicken production conditions. This approach, utilizing the same air sampling condition with the regards of air volume and airflow, makes the results comparable between poultry farms and chicken breeding systems. Application of a molecular approach on air filters allows reduced influence of inhibitors present in the matrix (boot swabs) since air is assumed to contain less inhibitors than faecal material. Additionally, during extraction of DNA, any inhibitors are more easily removed. Furthermore, an internal amplification control is included in the real-time PCR to provide reliable results. Using the present real-time PCR method, the sensitivity was $96.4 \%$. In only one case, Campylobacter was detected solely by cultivation of boot swab. Failure of air sample/PCR approach could be explained by low relative humidity in the house. Schroeder et al. (27) described low positivity of air samples in poultry houses with relative humidity below $44 \%$. The sensitivity observed in the present study is higher than the values from the validation studies shown in ISO 10272-1:2017, i.e. from $28 \%$ (chicken caecal material) to $64 \%$ (chicken skin) (20). However, the validation studies were carried out on other types of matrices with known level of contamination, and the sensitivities cannot be compared directly as the levels of contamination in the air samples are not known. It must also be taken into account that real-time PCR detects DNA from living, dead and VNBC bacteria, while the ISO method detects only living bacteria. As 
reported previously, the same air sampling and direct real-time PCR method applied for Campylobacter detection gave a detection limit of approximately 100 cell equivalents per 1 $\mathrm{m}^{3}$ of air in chicken house (11).

Due to the high sensitivity of the approach presented this might be optional in countries and farms with flocks with low Campylobacter-positive rates as culture-based methods might give more false-negative results, however this needs further investigation. Moreover, analysis of air filters with real-time PCR has an advantage over the reference ISO method giving the result in a much shorter time for Campylobacter detection in chicken flocks, i.e. one working day compared to four days, respectively.

Efficient measures for pathogen control in poultry environments are of primary importance to reduce direct or indirect food contamination. Campylobacter, Salmonella, E.coli, Listeria, Clostridium, Staphylococcus, and more are associated with increased veterinary costs and animal health, welfare and ultimately public health. The diagnostics is a primary preventive control measure, and molecular methods potentially identify various animal pathogens and prevents the limitations of traditional microbiology. The potential use of air sampling combined with PCR could be a valuable tool in such scenario for rapid and cost-effective diagnostics of target microbes. Finally, the method herein described could be also applied in the field by using portable PCR systems making point of care diagnostics possible, even if further validation studies are necessary.

In conclusion, air sampling combined with real-time PCR is proposed as a multi-purpose, low-cost and convenient screening method that can be up to four times faster and four times more sensitive than the current boot-swab testing scheme used for screening biosecured 
335

336

337

chicken production. However, to obtain both isolates and PCR results, enriched swab samples should be preferred.

Supplemental Material

Supplemental Table S1

\section{Acknowledgements}

The present work was part of the One Health EJP project that has received funding from the European Union's Horizon 2020 research and innovation programme under grant agreement No 773830 (2018-2022). The Polish part of this study was also supported from the financial resources for science for the years 2018-2022 granted for the implementation of an international co-financed project. The farmer organizations and farmers that provided us access to chicken houses are acknowledged for their kind collaboration. The Czech part of the study was also carried out with financial support of the Ministry of Education, Youth and Sport CZ.1.05./2.1.00/19.0385.

\section{References}

1. EFSA Panel on Biological Hazards (BIOHAZ). 2011. Scientific opinion on Campylobacter in broiler meat production: control options and performance objectives and/or targets at different stages of the food chain. EFSA J 9(4):2015.

2. Kaakoush NO, Castaño-Rodríguez N, Mitchell HM, Man SM. 2015. Global epidemiology of Campylobacter infection. Clin Microbiol Rev 28:687-720. 
3. Geissler AL, Bustos Carrillo F, Swanson K, Patrick ME, Fullerton KE, Bennett C, Barrett

K, Mahon BE. 2017 Increasing Campylobacter Infections, Outbreaks, and Antimicrobial

Resistance in the United States, 2004-2012. Clin Infect Dis 65:1624-1631.

4. ECDC. 2019. Campylobacteriosis. In: European Center for Disease Control and

Prevenetion. Annual epidemiological report for 2017. Stockholm, Sweden

5. European Food Safety Authority and European Centre for Disease Prevention and Control. 2019. The European Union One Health 2018 Zoonoses Report. EFSA Journal 17:5926, 276

6. Josefsen MH, Bhunia AK, Engvall EO, Fachmann MS, Hoorfar J. 2015. Monitoring

Campylobacter in the poultry production chain-from culture to genes and beyond. J Microbiol Methods 112:118-125.

7. FRN. 2019. Docket Inspection Methods 24-3 Pathogen Reduction - Salmonella and Campylobacter 7/31/2019 No. FSIS-2014-0023; February 11, 2016

8. Anonymous. 2003. Directive 2003/99/EC of the European Parliament and of the Council of 17 November 2003 on the monitoring of Zoonoses and Zoonotic Agents amending Council Decision 90/424/EEC and repealing Council Directive 92/117/EEC. European Union, Brussels, Belgium.

9. EC. 2017. Commission Regulation (EU) 2017/1495 of 23 August 2017 amending Regulation EC No 2073/2005 as regards Campylobacter in broiler carcases. (European Union) Brussels, Belgium.

10. Hoorfar J. 2011. Rapid detection, characterization, and enumeration of foodborne pathogens. APMIS Suppl 133:1-24.

11. Sondergaard MS, Josefsen MH, Lofstrom C, Christensen LS, Wieczorek K, Osek J, Hoorfar J. 2014. Low-cost monitoring of Campylobacter in poultry houses by air sampling and quantitative PCR. J Food Prot 77:325-330. 
12. Bull SA, Allen VM, Domingue G, Jørgensen F, Frost JA, Ure R, Whyte R, Tinker D, Corry JE, Gillard-King J, Humphrey TJ. 2006. Sources of Campylobacter spp. colonizing housed broiler flocks during rearing. Appl Environ Microbiol 72:645-52.

13. Johnsen G, Kruse H, Hofshagen M. 2006. Genetic diversity and description of transmission routes for Campylobacter on broiler farms by amplified-fragment length polymorphism. J Appl Microbiol 101:1130-9.

14. Rosenquist H, Boysen L, Galliano C, Nordentoft S, Ethelberg S, Borck B. 2009. Danish strategies to control Campylobacter in broilers and broiler meat: facts and effects. Epidemiol Infect 137:1742-1750.

15. Hansson I, Engvall EO, Lindblad J, Gunnarsson A, Vagsholm I. 2004. Surveillance programme for Campylobacter species in Swedish broilers, July 2001 to June 2002. The Veterinary record 155:193-196.

16. Luechtefeld NW, Wang WL, Blaser MJ, Reller LB. 1991. Evaluation of transport and storage techniques for isolation of Campylobacter fetus subsp. jejuni from turkey cecal specimens. J Clin Microbiol 13:438-443.

17. Olsen KN, Lund M, Skov J, Christensen LS, Hoorfar J. 2009. Detection of Campylobacter bacteria in air samples for continuous real-time monitoring of Campylobacter colonization in broiler flocks. Appl Environ Microbiol 75:2074-2078.

18. Johannessen GS, Garofolo G, Di Serafino G, Koláčková I, Karpíšková R, Wieczorek K, Osek J, Hoorfar J. 2020. Campylobacter in chicken - critical parameters for international, multicentre evaluation of air sampling and detection methods. Food Microbiol 90:103455. 19. International Organization for Standardization. 2013. ISO 13307:2013. Microbiology of food and animal feeding stuffs — Primary production stage — Sampling techniques. International Organization for Standardization, Geneva, Switzerland. 
20. International Organization for Standardization. 2017. ISO 10272-1:2017. Microbiology of food chain - Horizontal method for detection and enumeration of Campylobacter spp.- Part 1: Detection method. International Organization for Standardization, Geneva, Switzerland. 21. Josefsen MH, Lofstrom C, Hansen TB, Christensen LS, Olsen JE, Hoorfar J. 2010 Rapid quantification of viable Campylobacter bacteria on chicken carcasses, using real-time PCR and propidium monoazide treatment, as a tool for quantitative risk assessment. Appl Environ Microbiol 76:5097-5104.

22. Malorny B, Hoorfar J, Hugas M, Heuvelink A, Fach P, Ellerbroek L, Bunge C, Dorn C, Helmuth R. 2013. Interlaboratory diagnostic accuracy of a Salmonella specific PCR-based method. Int. J. Food Microbiol 89:241-249.

23. Malher X, Simon M, Charnay V, Danguy des Déserts R, Lehébel A, Belloc C. 2011.

Factors associated with carcass contamination by Campylobacter at slaughterhouse in cecalcarrier broilers. Int J Food Microbiol 150:8-13.

24. Jore S, Viljugrein H, Brun E, Heier BT, Borck B, Ethelberg S, Hakkinen M, Kuusi M, Reiersen J, Hansson I, Olsson Engvall E, Løfdahl M, Wagenaar JA, van Pelt W, Hofshagen M. 2010. Trends in Campylobacter incidence in broilers and humans in six European countries, 1997-2007. Preventive Veterinary Medicine 93:33-41.

25. Boysen, L, Vigre H, Rosenquist H. 2011. Seasonal influence on the prevalence of thermotolerant Campylobacter in retail broiler meat in Denmark. Food Microbiology 28:1028-1032.

26. European Commission Regulation (EU) No 1190/2012 of 12 December 2012 concerning a Union target for the reduction of Salmonella Enteritidis and Salmonella Typhimurium in flocks of turkeys, as provided for in Regulation (EC) No 2160/2003 of the European Parliament and of the Council. Official Journal of the European Union, L 340/29. 
430 27. Schroeder MW, Eifert JD, Ponder MA, Schmale DG 3rd. 2014. Association of

431 Campylobacter spp. levels between chicken grow-out environmental samples and processed

432 carcasses. Poultry science 93:734-741.

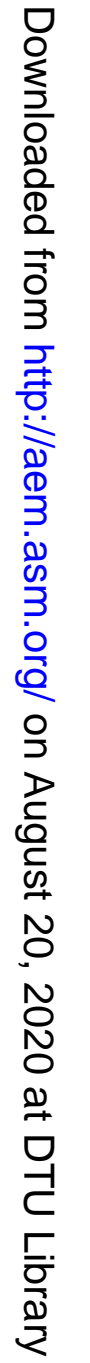


433 Table 1. Results from the use of cultivation (ISO 10272-1:2017) to detect Campylobacter 434 from boot swabs.

\begin{tabular}{cccccc}
\hline \multirow{2}{*}{ Country } & \multirow{2}{*}{$\begin{array}{l}\text { No. of } \\
\text { flocks }\end{array}$} & \multicolumn{4}{c}{ Do. of positive boot swabs } \\
\cline { 3 - 6 } & & Preston & Bolton & Preston & Bolton \\
\cline { 3 - 6 } Czech Rep. & 12 & 5 & 4 & 2 & 0 \\
Denmark & 18 & 0 & 0 & 6 & 0 \\
Italy & 10 & 10 & 10 & 10 & 10 \\
Norway & 10 & 0 & 0 & 0 & 0 \\
Poland & 12 & 6 & 6 & 5 & 0 \\
\hline
\end{tabular}

435

436

437 Table 2. Results from the use of cultivation and real-time PCR to detect Campylobacter from

438 air filters.

\begin{tabular}{ccccccc}
\hline \multirow{2}{*}{ Country } & No. of & \multicolumn{5}{c}{ No. of positive findings from air filters } \\
\cline { 3 - 5 } & flocks & \multicolumn{2}{c}{ Direct plating } & \multicolumn{2}{c}{ Enrichment } & \multirow{2}{*}{ Real-time PCR } \\
\cline { 3 - 5 } & & Preston & Bolton & Preston & Bolton & \\
\hline Czech Rep. & 12 & 0 & 0 & 1 & 2 & 5 \\
Denmark & 18 & 0 & 0 & 0 & 0 & 15 \\
Italy & 10 & 0 & 0 & 0 & 0 & 0 \\
Norway & 10 & 0 & 0 & 0 & 0 & 0 \\
Poland & 12 & 0 & 0 & 1 & 1 & 6 \\
\hline
\end{tabular}


Table 3. Campylobacter detection in flocks according to used approaches

\begin{tabular}{|c|c|c|c|c|c|c|}
\hline \multicolumn{4}{|c|}{ No. of flocks } & \multicolumn{3}{|c|}{ Diagnostic method } \\
\hline & Positive & & Negative & Air filter & $\begin{array}{l}\text { mbined wi } \\
\text { CR detecti }\end{array}$ & real-time \\
\hline $\begin{array}{c}\text { By both } \\
\text { approaches }\end{array}$ & $\begin{array}{l}\text { Detection } \\
\text { by boot } \\
\text { swabs and } \\
\text { cultivation } \\
\text { only }\end{array}$ & $\begin{array}{c}\text { Detection } \\
\text { by air filter } \\
\text { and real- } \\
\text { time PCR } \\
\text { only }\end{array}$ & $\begin{array}{c}\text { by both } \\
\text { approaches }\end{array}$ & Sensitivity & Specifity & $\begin{array}{c}\text { Diagnostic } \\
\text { accuracy }\end{array}$ \\
\hline 27 & 1 & 9 & 25 & $96.4 \%$ & $73.5 \%$ & $83.8 \%$ \\
\hline
\end{tabular}

441 
442 Fig. 1. Flow diagram showing detection of Campylobacter spp. from boot swabs samples (A)

443 and air filters (B) using ISO 10272-1:2017.

444

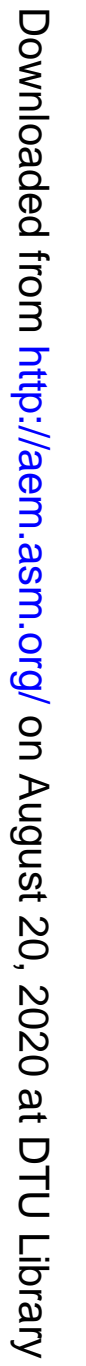


A Weigh in and add 9x
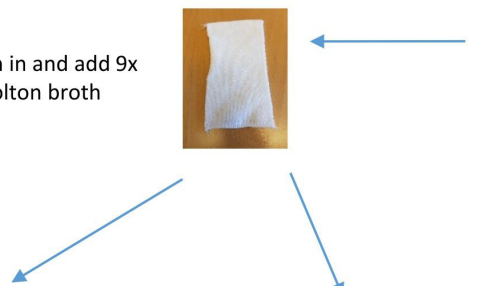

Plate $10 \mu$ directly on a mCCDA agar and a second of own choice

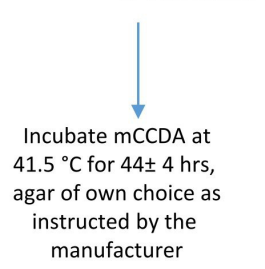

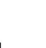
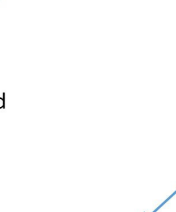

Freeze enrichment broth with glycerol at $-70{ }^{\circ} \mathrm{C}$ or below

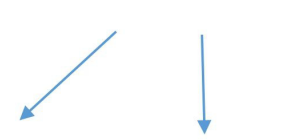
choice
Plate $10 \mu \mathrm{l}$ on mCCDA and second agar of own

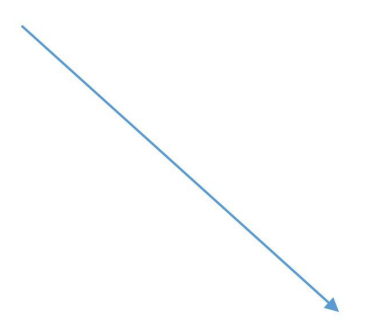

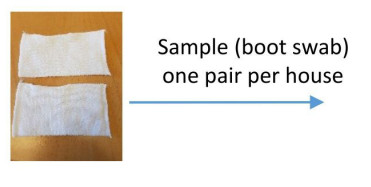

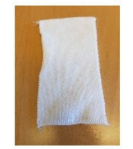

Weigh in and add $9 x$ Preston broth

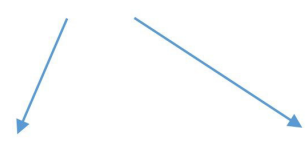

Incubate at $41,5^{\circ} \mathrm{C}$ for $24 \pm 2 \mathrm{hrs}$

Plate $10 \mu$ d directly on a mCCDA agar

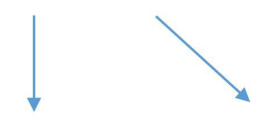

Plate $10 \mu \mathrm{l}$ on mCCDA

Freeze enrichment broth with glycerol at $-70{ }^{\circ} \mathrm{C}$ or below

Incubate at $41.5^{\circ} \mathrm{C}$ for $44 \pm 4 \mathrm{hrs}$ 
B
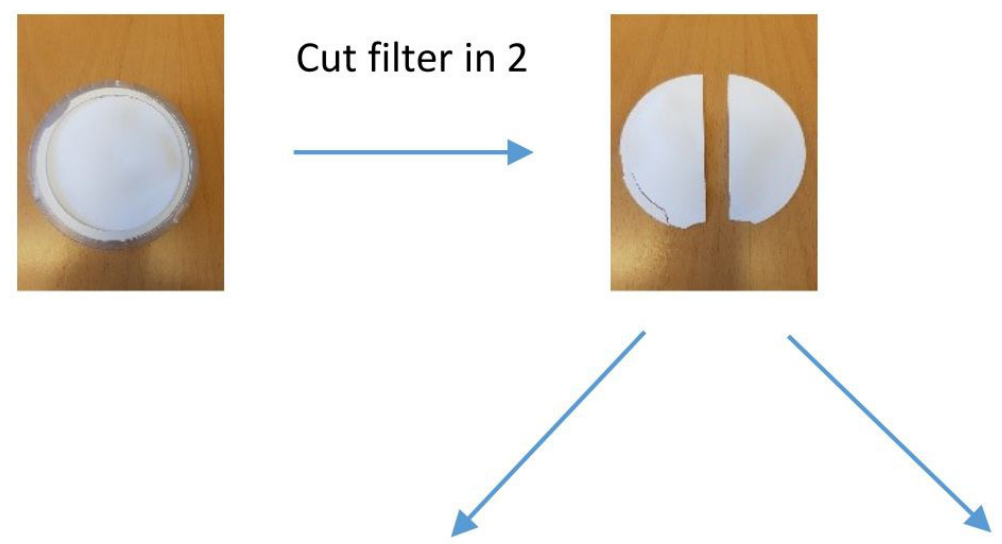

One half filter in tube (or similar) and add $10 \mathrm{ml}$ Bolton broth

One half filter in tube (or similar) and add $10 \mathrm{ml}$ Preston broth
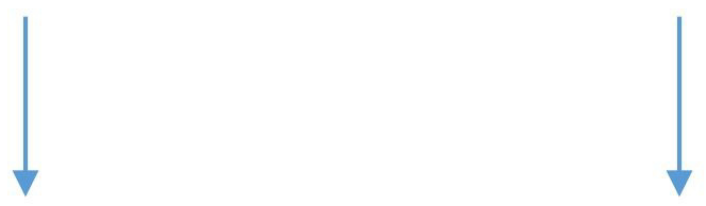

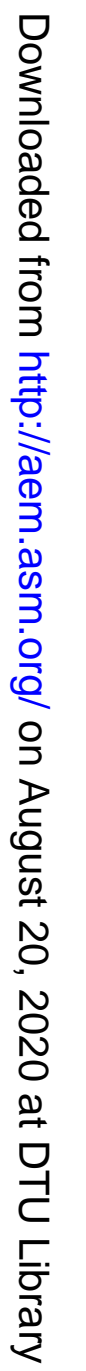

Proceed with direct plating and enrichment as described for boot swabs in the part A. 